\title{
Pengungkapan Estetika Fotografi “Instagramable” Di Era Pariwisata Destinasi Digital
}

\author{
Aji Susanto Anom Purnomo', Monica Revias Purwa Kusuma² \\ Visual Communication Design, Faculty of Technology Industry \& Informatics, \\ Telkom Institute of Technology Purwokerto, \\ ajisusanto@ittelkom-pwt.ac.id
}

\begin{abstract}
Salah satu strategi utama KEMENPAR dalam menarik wisatawan di tahun 2018 adalah menggunakan strategi "Destinasi Digital". Destinasi digital adalah strategi dimana pemangku kepentingan menciptakan suatu kondisi yang viral di media sosial berkaitan dengan objek wisata. Untuk menciptakan kondisi viral tersebut, KEMENPAR menciptakan spot-spot di objek wisata yang fotogenik sehingga wisatawan kemudian tergerak untuk merekam dan membagi pengalaman wisata mereka di media sosial khususnya Instagram. Salah satu faktor penting dalam menarik wisatawan lain dalam strategi "Destinasi Digital" adalah karya fotografi yang merekam keindahan pengalaman mereka di objek wisata dalam bingkai estetika "Instagramable". Oleh karena itu penelitian ini bertujuan untuk mengungkapkan estetika "Instagramable" yang mengkonstruksi keindahan persuasif karya-karya fotografi tersebut. Hasil dari penelitian ini adalah analisis deskriptif kualitatif melalui teori Estetika Fotografi dari gaya-gaya visual yang mengkonstruksi estetika "Instagramable", khususnya dalam mem-viral-kan objek wisata di Era "Destinasi Digital".
\end{abstract}

Kata kunci : destinasi digital, fotografi, instagram, pariwisata, estetika

\section{Aesthetic Disclosure of "Instagramable" Photography in the Era of Digital Destination Tourism}

One of KEMENPAR's (The Indonesian Tourism Ministry) main strategies in attracting tourists in 2018 is to use the "Digital Destination" strategy. Digital destinations are strategies where stakeholders create a condition that is viral on social media related to tourism objects. To create the viral condition, KEMENPAR created spots in photogenic attractions so that tourists would then be intrigued to record and share their travel experiences on social media, especially Instagram. One important factor in attracting tourists in the "Digital Destinations" strategy is a photographic work that captures the beauty of their experience in tourism objects by using the "Instagramable" aesthetic. Therefore this study aims to reveal the so called "Instagramable" aesthetic that constructs the persuasive beauty of these photographic works. The results of this study are descriptive qualitative analysis through Photography Aesthetic theory of visual styles that construct the "Instagramable" aesthetics, especially in connection with viral tourism objects in the "Digital Destinations" Era.

Keywords: digital destination, photography, instagram, tourism, aesthetics

Proses Review : 1 - 20 Agustus 2019, Dinyatakan Lolos: 22 Agustus 2019 


\section{PENDAHULUAN}

Dalam Rapat Koordinasi Nasional (RAKORNAS) Kementerian Pariwisata (KEMENPAR) I 2018 bertema "Digital Destination \& Nomadic Tourism" bertempat di Nusa Dua Convention Center (BNDCC) Bali, Menteri Pariwisata menyampaikan beberapa arahan tentang strategi untuk menarik wisatawan nusantara maupun wisatawan asing. Salah satu strategi arahan dari Menteri Pariwisata, Arief Yahya, adalah dengan meningkatkan jumlah objek wisata yang berkonsep destinasi digital. Destinasi Digital adalah sebuah destinasi yang heboh di dunia maya, viral di media sosial, dan nge-hits di Instagram. Untuk mendukung strategi tersebut, salah satu upaya dari KEMENPAR adalah membentuk Generasi Pesona Indonesia (GenPI), sebuah komunitas yang terdiri atas orang-orang berjiwa muda yang aktif melakukan promosi pariwisata melalui media sosial seperti blog, facebook, twitter, instagram, path, dan lain lain. Melalui GenPI dan pengguna media sosial yang aktif melakukan promosi objek wisata inilah diharapkan konsep destinasi digital akan berhasil merealisasikan target kunjungan 17 juta wisatawan mancanegara (wisman) dan 275 juta wisatawan nusantara (wisnus) pada tahun 2018.

Di era teknologi informasi saat ini, menurut hasil survei di seluruh dunia yang dirilis Everbrite-Harris Poll 2014, generasi milenial lebih memilih menghabiskan uang mereka untuk mendapatkan pengalaman (experience) dibandingkan barang (material goods). Generasi milenial merupakan konsumen yang paling haus akan pengalaman dibanding generasi-generasi sebelumnya, termasuk pengalaman dalam berwisata. Pengalaman berwisata yang kemudian diabadikan dalam sebuah bingkai fotografi adalah pemicu bagi viralnya sebuah objek wisata dalam konsep destinasi digital.

Salah satu aspek kekuatan sebuah karya fotografi adalah aspek estetika atau pengalaman estetik dari sebuah foto. Foto yang mampu memicu viralnya sebuah destinasi digital tentunya memiliki bingkai estetika tertentu yang mampu mempengaruhi perilaku dari orang yang melihat secara tidak langsung atau secara psikis. Foto-foto destinasi digital yang viral sering juga disebut dengan istilah "Instagramable". Istilah "Instagramable" mengacu pada lokasi-lokasi objek wisata yang fotogenik dan mengundang hasrat ingin mengabadikan pengalaman berwisata di tempat tersebut lalu membagikannya di media sosial. Foto-foto wisata menggambarkan bagaimana wisatawan membagikan pengalaman wisata mereka dan menggambarkan terjalinnya hubungan antara pengalaman wisata dengan fotografi. Selain itu, foto wisata juga bisa menghasilkan dampak yang dramatis pada orang lain. Dampak yang dramatis dari foto wisata tidak hanya ditimbulkan oleh pengalaman wisata yang ada dalam foto tersebut, namun juga pengalaman estetik yang terkandung di dalamnya. Kedua hal itu kemudian menjadi titik temu dalam strategi "destinasi digital" dan mempengaruhi psikis calon wisatawan berikutnya di media sosial. Titik temu tersebut adalah bingkai estetika "Instagramable" yang membuat viral sebuah foto objek wisata.

\section{TINJAUAN PUSTAKA}

Penggunaan gambar baik ilustrasi ataupun foto pada media sosial kini menjadi salah satu alat promosi tertinggi di bidang pariwisata. Menurut McQuail (dalam Liu,2016), pengguna tanpa sadar dipengaruhi oleh media yang mereka gunakan. Sehingga keputusan berwisata dapat berubah atau dipengaruhi oleh foto-foto objek wisata yang dilihat oleh para pengguna media sosial. Salah satu media sosial yang mempunyai layanan berbagi foto adalah Instagram. Instagram awalnya hanya digunakan sebagai sarana untuk fotografi secara daring, sekarang berubah sebagai penyedia informasi yang cepat, tepat dan akurat serta sebagai sarana untuk berpromosi, pemasaran, distribusi baik untuk barang ataupun jasa (Hoffman \& Novak; Doolin et al; \& Sweeney dalam Fatanti \& Suyadnya, 2015). Dalam konteks pariwisata, fotografi secara daring menciptakan persepsi yang positif dari wisatawan mengenai objek wisata. Hal itu menyebabkan wisatawan lebih percaya pada foto dan opini wisatawan lain dalam menentukan tujuan berwisata. Foto dalam hal tersebut berfungsi sebagai wahana berbagi pengalaman. Sebuah interaksi batiniah, yang dipicu oleh pengalaman estetik ketika melihat sebuah foto juga sekaligus pengalaman wisata.

Mengenai pengalaman estetik sendiri adalah salah satu dampak yang dialami oleh orang yang melihat sebuah karya seni, dalam hal ini khususnya karya fotografi. Menurut Soedjono (2007 ; 8-18), tataran estetis karya fotografi bisa dikategorikan menjadi dua, estetika dalam tataran ideasional dan estetika dalam tataran tehnikal. Dari sisi ideasional meliputi : tema, konsep dan pesan visual yang terkandung dan dapat dibaca dari isi foto yang ditampilkan. Sedangkan sisi teknikal meliputi : teknis kamera, komposisi, pencahayaan, sudut pandang (angle). Fotografi melalui kaidah estetikanya menawarkan kemungkinan yang tadinya tidak mungkin atau tidak pernah dialami oleh manusia menjadi mungkin dalam rangka menuangkan pengalaman dan kejadian yang bersifat tekstual dan imajinatif menjadi visual imajinatif untuk kemudian dieksplorasi menjadi visual dokumentatif yang lebih faktual secara visual kontekstual. (Soedjono, 2009:14)

\section{PERNYATAAN MASALAH}

Estetika "Instagramable" merupakan sebuah wahana bagi sebuah foto wisata untuk menjadi viral di media sosial. Oleh karena itu pengungkapan kaidah estetika baik dari sisi ideasional maupun teknikal akan bermanfaat bagi fotografer atau penggerak strategi wisata "destinasi digital", supaya tercapai target yang diinginkan. Pengungkapan ini secara deskripsi akan memberikan gambaran 
bagaimanakah sebuah "foto" memberikan dampak dramatis dan persuasif dari sisi pengalaman wisata serta pengalaman estetik.

\section{METODOLOGI}

Pengumpulan data penelitian menggunakan metode observasi dan studi pustaka. Kemudian data yang sudah terkumpul dianalisis dengan metode deskriptif. Metode deskriptif yang dimaksud adalah penggambaran suatu keadaan yang berjalan pada saat proses penelitian. Dalam metode deskriptif ini memiliki prinsip utama mengolah dan menganalisis data menjadi sebuah narasi sistematis, teratur, terstruktur dan bermakna tertentu sebagai sebuah paparan pemecahan masalah penelitian. Pengambilan data menggunakan metode random sampling di akun instagram @instapurwokerto, media sosial untuk mempromosikan objek wisata di kota Purwokerto. Data yang diambil dan dianlisis dalam penelitian ini akan dibatasi sejumlah 5 (lima) foto.

\section{HASIL ANALISIS}

Dari sample foto dalam penelitian ini menghasilkan beberapa aspek estetika yang meliputi aspek teknikal dan ideasional. Aspek teknikal meliputi : teknis kamera, komposisi, pencahayaan, angle. Sedangkan aspek ideasional meliputi : tema, konsep, dan pesan visual yang terkandung dan dapat dibaca dari isi foto yang ditampilkan.

Melalui pengungkapan aspek teknikal dan ideasional dari estetika beberapa sample foto di akun@instapurwokerto yang sudah dipaparkan di atas, dapat ditarik beberapa ciri kesamaan dari estetika foto destinasi digital yang "instagrammable".

Aspek teknikal dari foto-foto tersebut rata-rata memiliki pencahayaan yang merata dari area shadow dan highlight, sehingga detail keseluruhan objek wisata bisa terlihat dan pemandangan luas terlihat jelas. Penggunaan Depth of Field (DOF) diatur supaya ketajaman dapat merata dari latar depan hingga latar belakang, namun untuk kondisi tertentu seperti pemotretan di malam hari, DOF diatur supaya mendapatkan pencahayaan yang cukup dan merata. Pencahayaan yang pakai dalam pemotretan foto-foto ini kebanyakan menggunakan pencahayaan alami atau available light, karena diambil oleh wisatawan yang tidak memiliki alat lengkap seperti fotografer professional.

Sudut pandang atau Angle yang digunakan wisatawan saat mengambil foto-foto di destinasi digital cukup bervariasi, ada yang menggunakan high angle atau eye view untuk mengambil obyek. Pertimbangan-pertimbangan itu melihat dari obyek apa yang ingin ditampilkan sehingga menghasilkan suatu foto yang bisa memamerkan suatu destinasi digital dengan baik.

Dari sisi komposisi fotografi secara keseluruhan ada per- samaan. Komposisi foto-foto tersebut diatur supaya daya tarik foto lebih menonjol atau eyecatching. Komposisi diatur dengan proporsi manusia yang menjadi objek foto hanya $10-20 \%$ dari proporsi keseluruhan bidang foto. Foto-foto tersebut lebih menonjolkan objek wisata yang luas dan menarik, sehingga seolah-olah manusia hanya pelengkap foto saja. Fokus perhatian atau point of interest oada ke lima foto tersebut memiliki kesamaan yaitu memusatkan perhatian pada background atau foreground yang menampilkan keindahan atau keunikan suatu objek wisata dan mengesampingkan manusia yang biasanya menjadi objekk utama suatu foto.

Aspek Ideasional dari foto-foto sample dari akun@instapurwokerto yang "Instagrammable" tersebut memiliki beberapa persamaan. Tema yang diambil dari foto-foto tersebut kebanyakan adalah menikmati keindahan pemandangan objek wisata. Properti buatan yang melengkapi keindahan objek wisata seperti panggung berbentuk hati, pintu dan sarang burung memegang peranan penting dalam menampilkan estetika yang "Instagrammable". Properti tersebut memberikan pesan visual yang tidak hanya memberikan tambahan keindahan bagi objek wisata, namun juga memberikan pemaknaan alternatif terhadap objek wisata sebagai sebuah bentuk petualangan selfie atau aktualisasi diri sebagai seorang petualang bukan lagi seorang wisatawan. Konsep petualangan dan penemuan ini menjadikan objek wisata yang tidak begitu terkenal menjadi viral dan wisatawan lain tertarik untuk mengunjunginya juga. Walaupun tidak indah pada awalnya, namun keindahan yang tersembunyi tersebut mampu dimunculkan dengan beragam properti buatan manusia yang menjadikan objek tersebut 'Instagrammable'.

\section{SIMPULAN}

Berdasarkan hasil yang diperoleh, penelitian ini memberi kita pengetahuan tentang ciri-ciri estetika foto-foto destinasi digital yang 'Instagrammable'. Dalam Estetika 'Instagrammable' teknik yang digunakan beragam, semua teknik yang digunakan bertujuan memamerkan suatu obyek wisata menjadi destinasi digital yang patut dikunjungi karena keindahannya. Hal lain yang menonjol yaitu manusia tidak lagi menjadi obyek utama pada suatu foto tersebut karena hanya menghiasi 10-20\% dari keseluruhan bidang foto yang menunjukkan keindahan dari suatu destinasi digital. Selain keindahan tempat wisata yang ditonjolkan dengan baik menggunakan teknik foto yang tepat, ada juga aspek ideasional di baliknya. Tema dan konsep yang diangkat memiliki keterikatan antara obyek wisata dan properti yang ada di tempat tersebut. Properti foto yang disediakan saling melengkapi sehingga semakin menarik ketika di foto. Disini ditemukan bahwa destinasi dibuat tidak hanya mengandalkan kekayaan alam suatu daerah atau objek wisata menjadi daya tarik utamanya, tetapi harus ada kreatifitas dalam mengolah tempat tersebut agar lebih eyecatching dan bermakna jika difoto oleh wisatawan. Ob- 
Tabel 1. Aspek Teknikal

\begin{tabular}{|c|c|c|c|c|}
\hline SAMPEL FOTO & TEKNIS KAMERA & KOMPOSISI & PENCAHAYAAN & ANGLE \\
\hline & $\begin{array}{l}\text {-DOF luas untuk menampil- } \\
\text { kan ketajaman dari latar } \\
\text { depan dan belakang. } \\
\text {-Bagian highlight dibuat } \\
\text { sedikit overexposure. } \\
\text {-Saturasi warna dan kontras } \\
\text { natural. }\end{array}$ & $\begin{array}{l}\text { - Simetris } \\
\text { - Manusia 10\% dari obyek } \\
\text { keseluruhan } \\
\text { - 90\% menonjolkan keinda- } \\
\text { han objek wisata }\end{array}$ & Available light & High angle \\
\hline
\end{tabular}

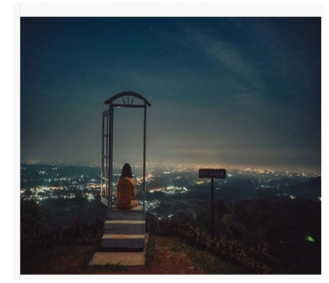

-DOF sempit karena kondisi pemotretan di malam hari, sehingga latar belakang perkotaan out of focus, cahaya lampu kota.

-kontras rendah dan bagian shadow lebih dinaikkan exposurenya untuk menampilkan detail. hanya menampilkan pijar
- Rule of thirds - Manusia 10\% dari obyek keseluruhan - 90\% menonjolkan keindahan objek wisata
Available light $\quad$ Eye view

Available light

Eye view

- Simetris

- Manusia 10\% dari obyek

menampilkan ketajaman

keseluruhan

- 90\% menonjolkan keinda-

han objek wisata

- Shutter Speed tinggi

(Freeze).

- Saturasi warna dan kontras

natural.

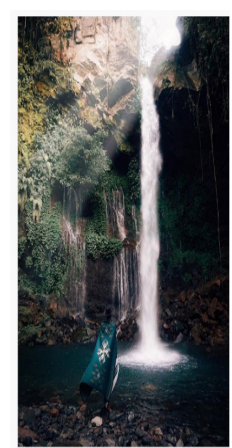

- DOF luas untuk

menampilkan ketajaman

dari latar depan dan be-

lakang.

- Bagian highlight dibuat sedikit overexposure.

- Saturasi warna dan kontras natural.
- Rule of Thirds

Available light

Eye view

- Manusia 10\% dari obyek

keseluruhan

- 90\% menonjolkan keinda-

han objek wisata

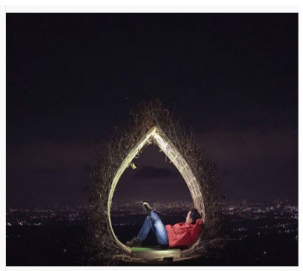

- DOF sempit karena kondi-

si pemotretan di malam hari, -

- Simetris

Available light and Eye view

sehingga latar belakang

Flash light

perkotaan out of focus,

keseluruhan

hanya menampilkan pijar

- 90\% menonjolkan keinda-

cahaya lampu kota.

han objek wisata

- Kontras rendah dan bagian shadow lebih dinaikkan ex-

posurenya untuk menampilkan detail. 
Tabel 1. Aspek Ideasional

\begin{tabular}{|c|c|c|c|}
\hline SAMPEL FOTO & TEMA & KONSEP & PESAN VISUAL \\
\hline$\square$ & $\begin{array}{l}\text { Bersantai menikmati keindahan } \\
\text { alam }\end{array}$ & $\begin{array}{l}\text { - Orang yang difoto bersandar } \\
\text { santai dan melihat ke air terjun } \\
\text { seolah menikmati pemandan- } \\
\text { gan. } \\
\text { - Penggunaan properti pang- } \\
\text { gung kayu berbentuk jantung } \\
\text { hati buatan manusia menambah } \\
\text { daya tarik dari foto tersebut. }\end{array}$ & $\begin{array}{l}\text { Simbol jantung hati sering di- } \\
\text { gunakan sebagai lambang dari } \\
\text { perasaan cinta atau kedamaian. } \\
\text { Pesan yang bisa ditangkap dari } \\
\text { foto ini adalah keindahan alam } \\
\text { atau obyek wisata menjadi } \\
\text { ungkapan rasa cinta dari } \\
\text { wisatawan terhadap siapapun } \\
\text { yang melihat fotonya di media } \\
\text { sosial, atau bisa juga menjadi } \\
\text { ungkapan rasa damai saat men- } \\
\text { gunjungi obyek wisata ini. }\end{array}$ \\
\hline
\end{tabular}

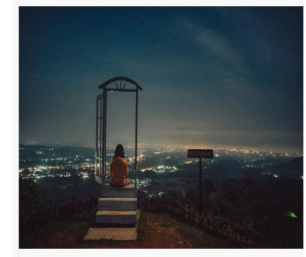

Menikmati keindahan kota dari atas - Orang yang difoto duduk bukit

menghadap ke depan, di kamera hanya terlihat punggungnya yang memperlihatkan bahwa dirinya sedang menikmati keindahan kota dari atas.

- Penggunaan properti pintu berwarna putih dan terbuka buatan manusia menambah daya tarik dari foto tersebut.
Dalam foto ini pintu yang digunakan sebagai properti foto memberikan pesan visual yang bermakna ganda,bisa bermakna jalan masuk kedalam rumah,atau jalan keluar menuju dunia luar yang penuh petualangan.

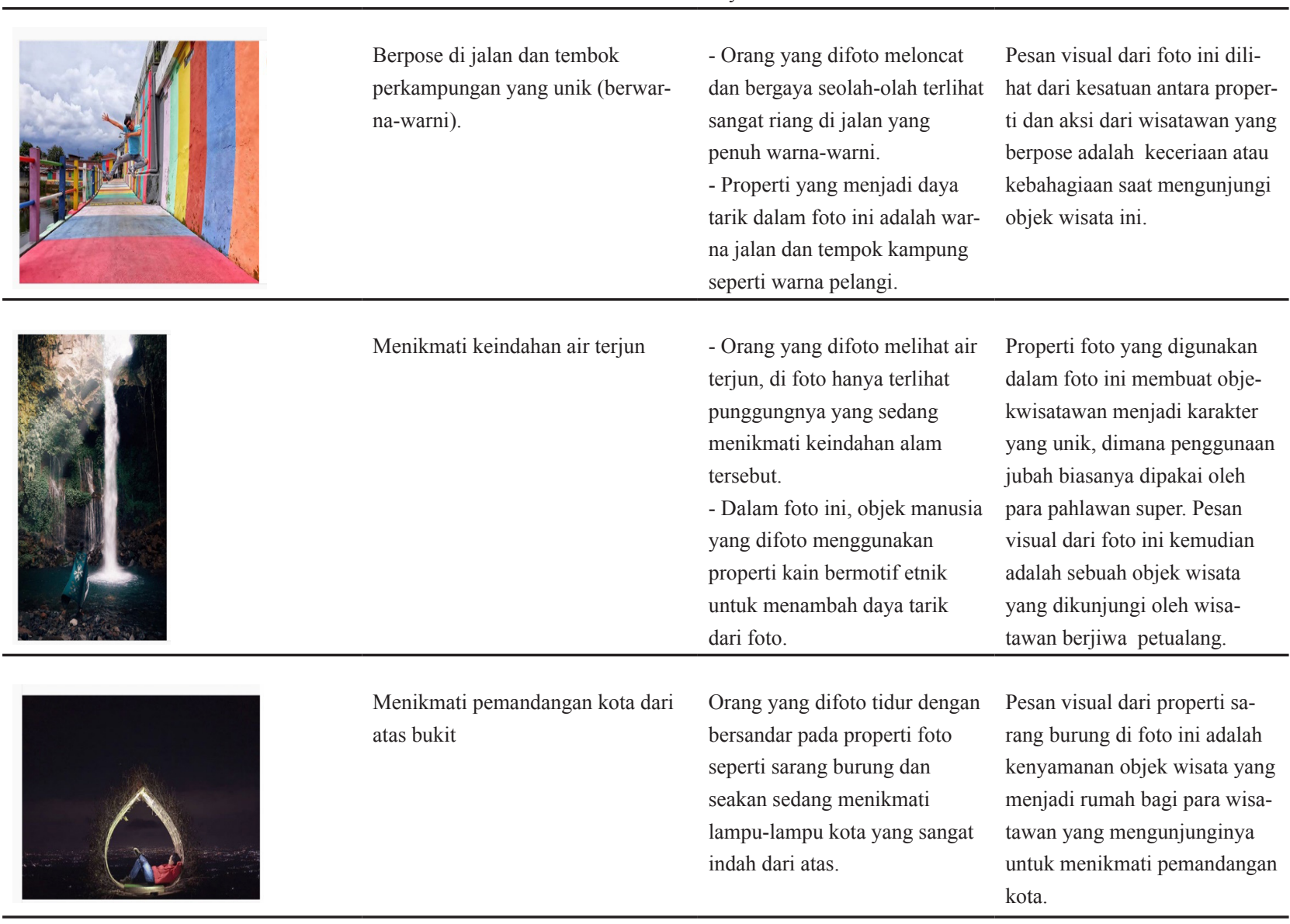


jek wisata yang kurang menarikpun bisa dirancang supaya menarik dengan menggunakan properti foto buatan yang mendukung estetika "Instagrammable". Foto-foto destinasi digital yang 'Instagrammable' didukung oleh kedua keterikatan tersebut sehingga dapat memviralkan suatu obyek wisata di era pariwisata destinasi digital dengan menghasilkan foto yang menarik \& unik.

\section{DAFTAR RUJUKAN}

\section{Acuan dari buku dengan satu, dua, dan tiga penulis}

Fatanti, M.N.,\& Suyadnya, I.W. (2015). Beyond User Gaze: How Instagram Creates Tourism Destination Brand?. Procedia - Social and Behavioral Sciences, 211, 1089-1095: http://doi.org/10.1016/j.sbspro.2015.11.145

\section{Acuan Bab dalam Buku}

Liu, B. (2016). A Flash of Culinary Tourism : Understanding The Influences of Online Food Photography on People's Travel Planning Process on Flickr, (January 2013)

Soedjono, Soeprapto. 2007. Pot-Pourri Fotografi. Jakarta. Universitas Tri Sakti.

Soedjono, Soeprapto. 2009. Fotografi dalam Konstelasi Budaya Visual Indonesia. Buklet Pengukuhan Guru Besar Prof. Drs. Soeprapto Soedjono. Yogyakarta:BP ISI.

Pramana, I Made Bayu. Desember 2017. Kajian Estetika Fotografi pada Kartu Pos Pariwisata Bali Karya Sujana Tahun 1970-1990am. Jurnal Prabangkara. ISSN 1412-0380. Vol 21 : Nomer 2. 80-85.

\section{Acuan dari dokumen online (website/internet)}

http://validnews.co/Optimalisasi-Ekosistem-Kepariwisataan-Via-Digital-1Cy

http://mediaindonesia.com/read/detail/153511-destinasi-digital-berpotensi-tarik-wisatawan-milenial

https://www.viva.co.id/gaya-hidup/travel/1018847-destinasi-digital-pertama -di-dunia-ada-di-indonesia 